\title{
Obituary
}

\section{Charles Alexander (Lex) Parker 1916-2001}

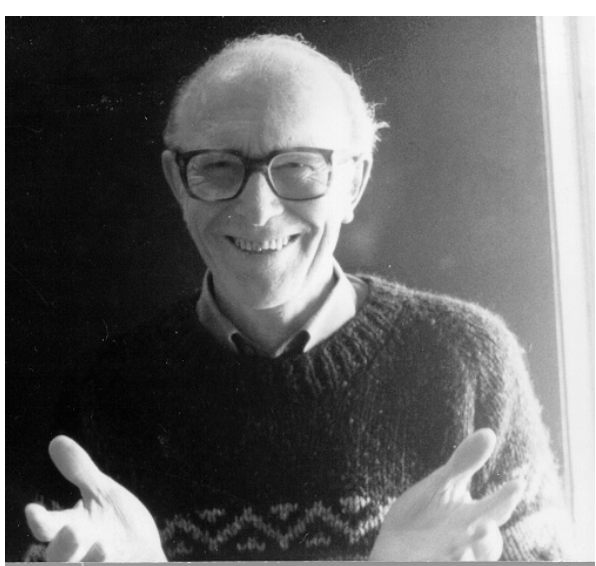

Lex Parker was brought up on his fathers 1800 hectare wheat/sheep farm near Kulin, a small town in the Western Australian wheat belt. This personal experience with the land and the hardships and problems faced by farmers gave Lex the awareness to dedicate his career to their cause. Lex had the ability to speak the language of farmers and farmers knew they were dealing with an international expert whose scientific knowledge was in demand in many countries and by the United Nations itself.

When phone calls for help came from the wheat belt, the eminent academic would not hesitate to drive out for a look at the soil and stay for a discussion afterwards. There would be no question of a consultant's fee. Professor Parker considered finding practical solutions to farming problems part of his job. He also genuinely liked farmers and they liked him - they saw him as one of their own.

Gregarious and good humoured, he would sometimes have to be almost dragged away to other appointments.

When he turned seven, his mother, a trained teacher, taught him at home for a couple of years before sending him to the local primary school. She resumed lessons in his early teens. The Correspondence Department then took over and young Lex later won a scholarship to the then Muresk Agricultural College.

Because his father had been gassed in France during World War 1, Lex had to remain on the farm while his younger brother Bevan went off to World War 2. When hostilities ended and Bevan returned, Lex, then aged 29, enrolled in the agriculture department at the University of Western Australia (UWA). In 1950 he spent a year studying microbiology at the University of Melbourne and then returned to study soil microbiology at UWA. He researched non-symbiotic nitrogen fixation, then legume rhizobial problems and later take-all, a serious root disease of cereal crops.

In 1959 Lex was appointed to senior lecturer at UWA and by 1973 he was honoured with a personal chair, a professorial post awarded to academics of particular distinction.

A Sri Lankan, Krishnapillai Sivasithamparam (Siva), was one of the many recipients of the professor's generosity. Professor Parker invited him to UWA to pursue doctoral research, found him a house, taught his wife to drive and shared hot curries with them. Professor Siva, who has succeeded Professor Parker at UWA, described his mentor as 'a great soul'. The development of the use of legumes to introduce nitrogen into the soil was just one of his contributions. 'He was a man of ideas, which others took up and ran with'.

Former student Professor Mike Dilworth, of Murdoch University, wrote in a tribute that Lex was a wonderful human being, adding: 'I never met any scientist with as strong a sense of absolute intellectual honesty as Lex Parker'.

Lex was especially interested in helping farmers and scientists in Third World countries, serving with United Nations agencies and contributing his knowledge in India, Burma, Bangladesh, Tanzania, Nigeria and other countries.

After Professor Parker retired, he was named an emeritus professor and was an honorary researcher for a decade, with a special interest in the role of earthworms in wheat fields.

When he was a student at Currie Hall, he met his future wife, Dorothy, who was to become an anthropologist on the staff at UWA and who sometimes accompanied him on overseas study trips, during which he insisted research, not tourism, was the mission.

He is survived by Dorothy, their three children, David, Anthea and Janet, and two grandchildren

The Lex Parker Prize in Applied Microbial Ecology was recently set up in his honour at the University of Western Australia.

Adapted from The West Australian by Michael Day 